\title{
ПЕДАГОГИЧЕСКИЙ ПРАКТИКУМ
}

Самира Мир-Багирзаде

\section{Русский язык в Азербайджане}

Автор рассказывает о собственной методике преподавания русского языка в азербайджанской аудитории. С.А. Мир-Багирзаде, И.М. Алиева и М.3. Мирзоева разработали учебное пособие «Русский язык» для студентов факультета международных отношений Бакинского славянского университета. В учебном пособии систематизируются важнейшие сведения по фонетике, орфографии, морфологии, синтаксису, пунктуации русского языка. Значительное место отводится работе с текстами, подобранными в соответствии со специальностью студентов, другим упражнениям. Пособие расширяет лингвистический кругозор за счет предлагаемого лексического материала (толкование слов, фразеологизмы, этимология слов, рубрика «Это интересно», «Почему мы так говорим», «Это надо знать»).

Ключевые слова: Азербайджан, ООН, русский язык в Азербайджане, русский язык в вузе, дипломатия, Бакинский славянский университет

Русский язык изучается на всех континентах, это один из шести официальных и рабочих языков ООН. Каждая четвертая книга, печатающаяся в мире, выходит на русском языке. Значительная часть книг переводится с русского языка на сотни других языков мира. Высоко ценит русский язык наша страна - Азербайджан. В Азербайджане есть также несколько рус-

\section{Мир-Багирзаде}

Самира Алтай кызы,

кандидат филологических наук, доцент по специальности «Культурология», ведущий научный сотрудник отдела «Культурология» Национальной академии наук

Азербайджана (Баку), samiramb777@mail.ru скоязычных школ, а также высших учебных заведений, где наряду с азербайджанским сектором есть и русский. Бакинский Славянский университет один из многих азербайджанских вузов, где изучают русский язык. Особенность нашего университета в том, что студенты глубоко знакомятся с русской культурой, а изучая русский язык, могут выбрать специализацию: лингвистическую, дипломатическую и др.

Наши студенты - будущие дипломаты - хорошо понимают, что искусство дипломатии подразумевает безупречное владение языком страны. Языку дипломатии в целом присуща книжная, «высокая» лексика, служащая для создания известной торжественности и придания документу подчеркнутой значимости. Используются также выражения, связанные с этикетом и представляющие собой общепринятые формулы вежливости: $M u$ нистерство иностраннъх дел... свидетельствует свое почте ние посольству... и имеет честь сообшить; Прошу Вас, господин Посол, принять уверения в моем весъма высоком уважении и т. п.

Специфичны лексика и фразеология дипломатических документов: аккредитовать, вербальная нота, вери тельная грамота, вольный город, демарш, дипломатическая неприкосновенность, дипломатический корпус, коммюнике, консульская конвениия, морской атташе, поверенный в делах, прелиминарный договор, преамбула, ратификаиия, уль тиматум и т. д. [1]. Значительная часть этой лексики интернациональна, некоторые термины передаются как русскими буквами, так и в латинском написании: персона грата, персона нон грата, статус-кво (status quо), casus belli.

Изучив язык в совершенстве, можно красиво говорить на языке дипломатии. Дипломатическому языку не чужды некоторые элементы образности. Например, в зарубежной печати сочетание Даунинг-стрит употребляется в значении «Министерство иностранных дел Великобритании» (на этой небольшой улице в Вестминстере располагается ряд ключевых правительственных резиденций), Кэ д’Орсэ - в значении «Министерство иностранных дел Франции» (на этой парижской набе- 
режной располагается МИД Франции), Белый дом (резиденция президента США) - в значении «президент США» или «правительство США», Елисейский дворец (резиденция президента Франции) - в значении «правительство Франции» и т. п.

Для изучения русского языка на факультете международных отношений Бакинского славянского университета было издано учебное пособие «Русский язык» [2] (авторы: кандидат филологических наук Самира МирБагирзаде, кандидат педагогических наук Ирана Алиева, Марьям Мирзоева), которое используется и по сей день.

В учебном пособии систематизируются важнейшие сведения по фонетике, орфографии, морфологии, синтаксису, пунктуации русского языка. Значительное место отводится работе с текстами, подобранными в соответствии со специальностью студентов, другим упражнениям.

Цели пособия: 1) систематизировать и обобщить орфографические и пунктуационные навыки учащихся на базе изучения грамматики и осознания сущности русской фонетики, орфографии, морфологии, синтаксиса, пунктуации и стилистики; 2) расширить лексику учащихся; 3) исправить наиболее типичные для учащихся отступления от лексико-грамматических норм русского языка. Практические цели пособия обусловили его содержание и структуру.

Учебное пособие помогает студентам освоить русский язык многопланово; задания, помогающие глубже понять художественное содержание, особенности и стили языка, сочетаются с устными и письменными упражнениями, способствующими логическому мышлению, освоению разных видов высказываний на литературные, общественно-политические, философские, нравственно-этические темы.
Сложность работы по русскому языку в азербайджанском отделении обуславливается различным уровнем подготовки учащихся. Это определило характер заданий в пособии - от очень простых до сравнительно сложных. Грамматический материал преподносится при помощи таблиц и схем. В пособие включены отрывки произведений мировой классики, а также пословицы и поговорки народов мира, которые помогут расширить кругозор обучающихся.

Текстовой материал подобран в соответствии со специальностью студентов. Учебно-познавательные тексты пособия разработаны и отобраны в соответствии с направлением данного факультета, где использованы материалы о дипломатических связях Азербайджана со многими странами, с широким включением лингвокультурных, этнографических и историко-культурных сведений о странах и народах.

Для развития речи и расширения лингвострановедческого кругозора к каждому уроку предлагается материал для самостоятельного чтения.

Учебное пособие поможет студентам азербайджанского отделения правильно, грамотно говорить и писать на русском языке, создавать различные по стилю и жанру сочинения-эссе, рефераты, аннотации, рецензии; делать выписки; правильно оформлять деловые бумаги, а также способствует развитию ораторских навыков.

Пособие расширяет лингвистический кругозор обучающихся за счет предлагаемого лексического материала (толкование слов, фразеологизмы, этимология слов, рубрика «Это интересно», «Почему мы так говорим», «Это надо знать»).

В конце книги приведен список литературы, который поможет студентам не только повторить и закрепить знания по русскому языку, но и осмыслить их по-новому. 


\section{Лumepamypa:}

1. Айдынов И.М. Русско-азербайджанский дипломатический словарь. Баку: Адилоглы, 2002. 248 с.

2. Мир-Багирзаде С.А., Алиева И.М., Мирзоева М.3. Русский язык: Учебное пособие для студентов факультета международных отношений. Баку: Нурлан, 2006. 516 с.

\section{Samira Altai kizi Mir-Bagirzade,}

PhD in Philology, Associate Professor in Cultural Studies,

Leading Researcher of «Cultural Studies» Department

of Azerbaijan National Academy of Sciences (Baku),

samiramb777@mail.ru

\section{Russian language in Azerbaijan}

The article explores the study of the Russian language in Azerbaijan using the example of the textbook «Russian Language» by S.A. Mir-Bagirzade, I.M. Aliyeva, M.Z. Mirzoeva for students of the Faculty of international relations of Baku Slavic University. The book provides theoretical information and developed system of exercises. The manual systematizes the key information on phonetics, spelling, morphology, syntax, punctuation of the Russian language. A significant place in this manual is given to work with texts selected in accordance with the specialty of students. A characteristic feature of the textbook is that it broadens the linguistic horizons of students through the proposed lexical material (interpretation of words, phraseological units, etymology of words, rubric «This is interesting», «Why do we say this», «This should be known»).

Keywords: Azerbaijan, United Nations, Russian language in Azerbaijan, Russian language in higher education, diplomacy, Baku Slavic University
Руслан Хайруллин, Елена Верхоломова, Любовь Суржикова

\section{Особенности преподавания учебного предмета «Литературное чтение» в начальных классах образовательных организаций с родным (нерусским) и русским (неродным) языком обучения}

Вслед за авторитетными учеными-методистами, занимающимися проблемой преподавания русского языка и литературы в национальной школе, авторы утверждают, что для обеспечения высокого уровня образования нерусских учащихся, нужны специальные учебники, которые учитывают психолого-педагогические особенности нерусских учеников. В качестве примера в статье рассматривается линия учебников по «Литературному чтению» под редакцией проф. М.В. Черкезовой, созданная специально для образовательных организаций с родным (нерусским) и русским (неродным) языком обучения.

Ключевые слова: учебный предмет «Литературное чтение»; школы с родным (нерус ским) и русским (неродным) языком обучения; обучение нерусских школьников основ ным видам речевой деятельности, пропедевтическое знакомство с художественной литературой

Ученые-методисты, занимающиеся проблемой преподавания русского языка и литературы в национальной школе (А.А. Липаев, Л.В. Тодоров, К.И. Нартов, К.В. Мальцева, М.В. Черкезова и др.), утверждают, что для обеспечения высокого уровня образования нерусских учащихся, нужны специальные учебники, которые учитывают психолого-педагогические особенности нерусских учеников.

До школы российские дети, для которых русский язык не является родным, в семье и детском саду развиваются в стихии родного языка. К моменту поступления в школу они слабо владеют русским языком. Поэтому им нужны специальные учебники, позволяющие им к концу начальной школы выйти на один уровень по русскому языку с русскоязычными учащимися массовых школ. 